\title{
The Historical Writing of Catherine II: Dynasty and Self-Fashioning in The Chesme Palace (Chesmenskii Dvorets)
}

It is well-known that the emergence of Visual Studies as a research field has encouraged academic interest in the simultaneous appearance as well as coexistence of textual and visual narratives, both of which contribute to social and cultural perceptions of creation. Following the example of some pioneering studies, ${ }^{1}$ modern scholars analyze visual and textual semantic references, interpret the way one formal structure gets reflected in another, and engage in a constant search for cases that demonstrate how textual and visual sources correspond and overlap. However, it is hard to get the balance right, as one type of source tends to come into view first and eventually starts to dominate the analysis. It is equally difficult to consider the parallel development of two spheres that do not necessarily synchronize, forcing one to evaluate what might be called a motion in motion.

The historiography of eighteenth-century Russian literature and culture is no exception. A good example here is the scholarly interpretation of the Russian Empress Catherine II's literary work called The Chesme Palace (Chesmenskii Dvorets), a short text originally written in French at the end of the century ${ }^{2}$ and published in Russian only in 1906. Until recently, the text has not drawn much scholarly attention. The current interest is apparently inspired by research into the portrait collection of the eponymous palace, ${ }^{3}$ the spot that the empress chose as the setting of her text.

1 Michael Baxandall. Painting and Experience in Fifteenth-Century Italy: A Primer in the Social History of Pictorial Style. Oxford: Oxford University Press, 1972; Leo Spitzer. "The 'Ode on a Grecian Urn,' or Content vs. Metagrammar.” Essays on English and American Literature, edited by Anna Hatcher. Princeton: Princeton University Press, 1962, pp. 67-97.

2 Ekaterina II. "Le Château de Chesme: L’Entretien des Portraits et Médaillons.” Sochineniya Ekateriny II na osnovanii podlinnykh rukopisey i ob'yasnitel'nymi primechaniyami akademika A. N. Pypina, vol. 12. St. Petersburg: Im'peratorskaya Akademiya Nauk, 1907, pp. 583-594.

3 Ekaterina Skvortsova. "Representing Imperial Power in Eighteenth-Century Russian Art: The Portrait Gallery of the Chesme Palace.” A Century Mad and Wise: Russia in the Age of the Enlightenment. Papers from the IX International Conference of the Study Group on EighteenthCentury Russia, Leuven 2014, edited by Emmanuel Waegemans, Hans van Koningsbrugge, Marcus

Note: The author expresses her gratitude to Vladimir Makarov for his assistance in translating the article. 
The Chesme Palace was by no means a figment of the empress's imagination. This still surviving building was designed by Yury Felten and erected between 1774 and 1777. It was named after the Battle of Chesme (1770), the most decisive naval victory in the Russian-Turkish War (1768-1774), and the one most glorified in eighteenth-century Russia. ${ }^{4}$ The palace stood on the road from St. Petersburg to Tsarskoye Selo with its imperial summer residences. It was often described as one of the empress's maisons de plaisance, ${ }^{5}$ resembling a medieval castle. Later, in 1780 a church was erected next to it, also designed by Yury Felten. Dedicated to the birth of St. John the Baptist, it was frequently called the Chesme Church. The ensemble was to mark the place where Empress Catherine II presumably received the news of the grand victory over the Ottoman Empire.

In the reign of Catherine II, the interiors of the ceremonial halls of the Chesme Palace featured fifty-nine portraits of monarchs from European royal houses (French, Swedish, Danish, Prussian, English, etc.). ${ }^{6}$ Some of these portraits were given to the empress as presents. ${ }^{7}$ Beside the portraits on the walls of ten of its rooms, the palace also featured a gallery of bas-reliefs of the Rurikids and Romanovs. Fifty-eight roundels by Fedor Shubin were placed just above almost the same number of monarchs' portraits. The front staircase led into the hall where the portrait of Catherine herself eventually appeared. Thus the empress symbolically opened the Russian dynastic series and was placed at the head of the entire community of European monarchs. Military symbolism was to be found in the marble statue of Catherine II as Minerva, an allegory of her victories. ${ }^{8}$

Interestingly, in Catherine's text, portraits of Russian and European rulers that hang on the walls of the Chesme Palace come to life, judge each other and discuss the role each of their sitters played in history. Thus, there arises the question of a possible interconnection between spatial and textual interpretations.

Levitt, and Mikhail Ljustrov. Groningen: Instituut voor Noord- en Oost-Europese Studies, 2015, pp. 455-469, p. 459.

4 Elena B. Smilyanskaya. "Osvoenie Sredizemnomor’ya vo vremya Russko-turetskoy voyny 1768-1774 gg.: realii i simvoly.” Istoricheskaya geografiya: prostranstvo cheloveka vs chelovek $v$ prostranstve. Materialy XXIII Mezhdunarodnoy nauchnoy konferentsii. Moskva, 27-29 yanvarya 2011. Moscow: RGGU, 2011, pp. 136-146.

5 Natalia I. Batorevich. Chesmenskii dvorets. St. Petersburg: Beloe i Chernoe, 1997, p. 42.

6 Skvortsova, "Representing Imperial Power," p. 465.

7 Batorevich, Chesmenskii dvorets, p. 52.

8 Elena V. Karpova. "Skul'pturnye izobrazheniia Ekateriny II (k evoliutsii allegoricheskogo obraza)." Ekaterina Velikaia: epokha Rossiiskoi istorii. Mezhdunarodnaia konferentsiia "Ekaterina Velikaia: epokha rossiiskoi istorii”: Tezisy dokladov. Sankt-Peterburg, 26-29 avgusta 1996, edited by Tatiana V. Artem'eva and Mikhail I. Mikeshin. St. Petersburg: SPbNTs, 1996, p. 240. 
Historians who recognize the significance of the two Chesme Palaces - the imperial residence and the text produced by the empress - typically put the built ensemble and its splendors at the center of their research, whereas the writing is considered as a type of supporting source. ${ }^{9}$ Moreover, The Chesme Palace is assumed to have been a sort of statement, similar to that of a gallery that aimed to declare the revival of Byzantium, ${ }^{10}$ promote the alliance with Austria in the late 1770 s, ${ }^{11}$ and ultimately proclaim "the high status of the Russian Empire as governed by a legitimate ruler and united by the ties of kinship with other European ruling houses."12

However, the history of the text (i.e. the chronological perspective, genre, and context) suggests an alternative interpretation of Catherine II's intentions.

As has been pointed out, the residence was commissioned in 1774; its décor was finalized in 1777. Unfortunately, the precise date of Catherine's written work is unknown. However, there is reason to believe that it was written in the mid1780 s, ${ }^{13}$ presumably not later than 1786 , since Frederick William II, who became King of Prussia that year, is still called "the Prussian Prince" in the text. Hence, The Chesme Palace was created about a decade later than the palace - and a decade and a half after the Battle of Chesme that had given the residence its name.

The genre of The Chesme Palace is not easily determined. Even though it has two parts and consists of dialogues and monologues, and despite the author's remarks and references to place and time, it can hardly be a play since, in its time, it would have been absolutely unstageable. One can assume that it was not produced for theatrical production since in eighteenth-century Russia images of the country's real tsars and emperors were prohibited on stage. The most likely interpretation of the genre is provided by Ekaterina Skvortsova, who argues that The Chesme Palace is a "dialogue of the dead," a form that "emerged in antiquity and enjoyed great popularity in European[...] literature of the eighteenth century." 14 She discusses the contribution to the genre made by David Fassman (1683-1744), a writer from Leipzig (Saxony) whose book Gespräche in dem Reiche derer Todten

9 Cf. Skvortsova, “Representing Imperial Power,” pp. 455-469, as well as Asen Kirin. "The Edifices of the New Justinian: Catherine the Great Reclaiming Byzantium.” Approaches to Byzantine Architecture and its Decoration: Studies in Honor of Slododan Curčić, edited by Mark Johnson and Robert Ousterhout. London: Ashgate, 2012, pp. 277-298.

10 Thus Asen Kirin in the essay cited in the previous note.

11 Skvortsova, “Representing Imperial Power," pp. 464-465.

12 Ibid., p. 466.

13 Irina V. Babich, Mikhail V. Babich, and Tatiana A. Lapteva, editors. Ekaterina II: Annotirovannaia bibliografiia publikatsii. Moscow: Rosspen, 2004, p. 250.

14 Skvortsova, “Representing Imperial Power,” p. 466. 
(Dialogues in the Realm of the Dead) reflected upon the Romanovs' rule in the early eighteenth century. ${ }^{15}$ Skvortsova also takes into account the influence of the gothic-novel tradition and suggests Horace Walpole's The Castle of Oranto (1764) as a possible source of inspiration for Catherine II's Chesme Palace. ${ }^{16}$

It is remarkable that all of the Chesme Palace portraits represented members of European royal houses who were alive when the gallery was created, ${ }^{17}$ whereas Fedor Shubin's bas-reliefs of the Rurikids and Romanovs presented the images of Russian princes and emperors who were truly in the realm of the dead. This created two almost equal-sized virtual groups - the dead and the living. Aiming to legitimize her status and her position in the state by acknowledging European kinship, Catherine II turned to the living. Would she be willing to deliver the same message by making the dead speak?

The context of the epoch is of no lesser significance. First, the specific figurative historicism of the Chesme Palace gallery was not unique in the period in question. On the contrary, in the eighteenth century, a special attitude to portraits had arisen, and the tradition of using them in the construction of certain semantic fields was quite current. A portrait always refers to an idea, and a monarch's portrait also has a symbolic meaning. In the early modern period, to possess the monarch's portrait was to possess a symbol, i.e. to have both a claim to an idea and the opportunity to bring it to life. In this "pre-psychological period," to borrow the term of Gennady Vdovin, ${ }^{18}$ a portrait would help one stand up to the challenges of self-identification and self-representation.

The data suggest that the use of a portrait as a tool of self-presentation came up in the eighteenth century. During the pre-Petrine period, such manifestations were quite unusual. Yet Prince Vasily V. Golitsyn, the principal minister of state in the late seventeenth century and the favorite of Princess Sofia, stands out. The interior of his Moscow house at Bolshaya Dmitrovka was quite unique. On the second floor, there was the so-called Large Table Chamber (Bolshaya

15 Ekaterina Skvortsova. "Russian Empresses and their Foreign Counterparts: The Validation of the New Title of the Russian Ruler in Illustrations of David Fassman's 'Dialogues of the Dead'." Newsletter of the Study Group on Eighteenth-Century Russia. 2016. http://www.sgecr.co.uk/ newsletter2016/skvortcova.html. Accessed 23 July 2018.

16 Ekaterina Skvortsova. "Illyustratsii k 'Razgovoram v tsarstve mertvykh': problema utverzhdeniya titula imperatora Rossii v XVIII veke.” Aktual'nye problemy teorii i istorii iskusstva: sbornik statey, vol. 5, edited by Svetlana V. Maltseva, Ekaterina Y. Stanyukovich-Denisova, and Anna V. Zakharova. St. Petersburg: NP-Print, 2015, pp. 503-512, pp. 508-509.

17 Skvortsova, "Representing Imperial Power," p. 459.

18 Gennadiy Vdovin. Persona - Individual'nost' - Lichnost': Opyt samopoznaniya v iskusstve russkogo portreta XVIII veka. Moscow: Moskva-Traditsiya, 2005, p. 121. 
Stolovaya Polata). This red and golden hall was grand in scale, incredibly full of light (46 windows), and refined in its décor. Apart from the pictures of the sun, the moon, the planets, and the signs of the zodiac on its ceiling, it was lavishly ornamented with mirrors and portraits, objects extremely rare at that time. ${ }^{19}$ The series of portraits displayed consisted of the images of the Russian monarchs (Prince Vladimir, Tsars Ivan IV, Feodor Ivanovich, and the first Romanovs - Tsars Mikhail, Alexey, and Feodor as well as the reigning Ivan and Peter) as well as Polish and possibly French kings. ${ }^{20}$

For the hundred years to follow, the number of halls and chambers where one could find portraits of members of the Russian dynasties, often together with foreign rulers, increased. Such canvasses formed the décor of royal residences in St. Petersburg, Peterhof, Gatchina, and aristocratic palaces such as Prince Alexander Menshikov's estate house at New Alekseevskoye (Novoe Alekseevskoye) and the Sheremetevs' palaces at Kuskovo and Ostankino in Moscow, to name but a few. $^{21}$

Secondly, Catherine's Chesme Palace dates to the second half of the Russian empress's reign, i.e. the 1780s, after the accession of Crimea to Russia (1783), which turned out to be a period in which the empress revised her views on Russian history. She moved away from her interest in Peter I, who for the previous couple of decades had been an absolute example of the Russian ruler and provided a legitimizing ground for those in power during the troubled epoch of the coup d'état. In the 1780s, the figure of Peter the Great began to lose sway

19 De la Nevill'. Zapiski o Moskovii, edited by Aleksandr Lavrov. Moscow: Allegro-press, 1996, p. 127. 20 Some portraits in the Chamber have not yet been identified. However, Golitsyn is known to have been Louis XIV's passionate admirer and made his son wear a medallion with the French king's image. Cf. Alexander G. Brikner. Istoriya Petra Velikogo, vol. 1. Moscow: TERRA, 1996, p. 169. 21 Olga S. Evangulova. Izobrazitel'noe iskusstvo v Rossii pervoy chetverti XVIII veka. Moscow: Izdatelstvo Moskovskogo universiteta, 1987, p. 272; Aleksey N. Grech. "Venok usad'bam." Pamyatniki Otechestva 32 (1994), pp. 5-190, pp. 110-111. - In the nineteenth century, the special attitude to portraits and the tradition of using them for the construction of specific semantic fields were still very much alive. Dynastic series, for instance, remained quite widespread. In the 1840s, after the reconstruction of the Lesser Hermitage, Emperor Nicholas I approved the creation of the Romanov gallery with the portraits of Russian monarchs in its western wing. The eastern wing at that time housed the monuments of Peter I's reign (including the famous 'Wax Persona,' i.e. a statue of the emperor made of wax by Francesco Rastrelli in 1725), as well as Peter the Great's personal possessions. Thus, Nicholas advanced his own version of dynastic history which differed from the older Catherinian one, as the first Emperor of Russia appeared as a figure of absolute authority. Cf. Vladimir I. Piliavskii and Vladimir F. Levinson-Lessing, editors. Ermitazh: Istoriia i arkhitektura zdanii. Leningrad: Avrora, 1974, pp. 192-193. 
in the discourse of power. This period was the birth of what might be called 'intellectual Slavophilism,' i. e. the time of seeking inspiration in pre-Petrine Russia. ${ }^{22}$

This was exactly the time when Catherine started studying the history of old Russia and reading the chronicles (letopisi). In 1786, she wrote several dramas whose plots were borrowed from Russian history: A Historical Scene from the Life of Rurik (Istoricheskoie predstavleniie iz zhizni Riurika, published anonymously), The Early Years of Oleg's Reign (in Imitation of Shakespeare) (Nachalnoie upravleniie Olega [podrazhaniie Shekspiru]), Igor (an incomplete sequel to Oleg's Reign), and a comic opera libretto called Boieslavich, the Bogatyr of Novgorod (Novgorodskii Bogatyr' Boieslavich).

Whereas modern scholars see in Catherine's folk-inspired texts the production of "a daring writer, pulling together elements of history, legend, popular song, and elevated poetry, all in the service of demonstrating Russia's legitimacy while glorifying its culture," 23 the empress's contemporaries found in these plays quite a number of political references. Oleg's Reign was seen as telling the story of the prince's campaign against Byzantium, and thus referring to the empress's plans concerning Constantinople. It was known that Prince Grigory A. Potemkin, Catherine II's military commander and statesman, helped edit the text. Boieslav$i c h$, the play where Novgorod submits to the strong power of the prince, was considered to express the empress's aim of proving that "strong rule" is preferable to "free" existence.

Catherine's use of the theatrical stage and literary journals to communicate her political and ideological views is no surprise at all. However, what is striking about this set of plays is the fact that the empress here takes a clear stand vis-à-vis her predecessors. This is, in a way, a novel view of the dynastic rule of the country, an expression of the need to address the first Russian royal dynasty, the Rurikids, rather than the Romanovs. It is no surprise, therefore, that in yet another text of the 1780s, Catherine II tries to reassess existing views on outstanding Russian monarchs.

In outward appearance, The Chesme Palace is a bitter satire both against most of Catherine's predecessors on the Russian throne and against the lifestyles of contemporary European monarchs. Nevertheless, it can be considered an expression of a different kind, an outstanding example of self-fashioning, to borrow

22 Vera Proskurina. Mify imperii: Literatura i vlast'v epokhu Ekateriny II. Moscow: Novoe literaturnoe obozrenie, 2006, pp. 135-146.

23 Lurana Donnels O'Malley. The Dramatic Works of Catherine the Great: Theatre and Politics in Eighteenth-Century Russia. Manoa: Ashgate, 2006, p. 204. 
Stephen Greenblatt's analytical approach, which arose from his studies of authorial self-consciousness in English Renaissance literature ${ }^{24}$ and has already been successfully applied to the study of some cases in eighteenth-century Russian history. ${ }^{25}$

In The Chesme Palace, the empress brings together historical characters from different eras: a court interpreter witnesses the portraits' conversation and "hastens to write everything down." ${ }^{26} \mathrm{He}$ "interprets," i.e. deciphers the language of imagery. At first, the empress focuses almost entirely on rulers of Russia. Elizabeth (Elizaveta Petrovna) appears simple-minded and carefree, "in manners and feelings much taken after her mother" (i.e. Catherine I) rather than her father (Peter the Great). Catherine I was only a "spouse of the monarch equally respected and feared." In her reign, the "state was administered as if on its own." ${ }^{27}$ Emperor Peter II is shown as a young sot in love with his aunt. ${ }^{28}$

Later on, Catherine II delves deeper into history than the eighteenth century: Tsar Ivan, the co-ruler of Peter the Great, was dysfunctional, and Peter's mother Natalia K. Naryshkina (like all her relatives) "of a shallow mind," while Tsar Alexei Mikhailovich appears as the model of a boneless man..$^{29}$

Catherine's European contemporaries from the royal houses of Austria and France are ridiculed as stupid spendthrifts, and the kings of Prussia (Frederick II and Frederick William II) as uneducated boors. ${ }^{30}$ For example, Frederick William II (the Prince of Prussia), who was an honorary member of the St. Petersburg Academy of Sciences, says: "How did you end up [...] clueless in the very midst of the session of the St. Petersburg Academy of Sciences? [...] This is nothing. [...] I yawned, covering my mouth with my hat as I am a man of good manners." ${ }^{31}$

In the second part of the text, the irony subsides, however. The conversation moves into the room that features the portraits of Prussian monarchs and the

24 Cf. Stephen Greenblatt. Hamlet in Purgatory. Princeton: Princeton University Press, 2002. Cf. also his Renaissance Self-Fashioning: From More to Shakespeare. Chicago: University of Chicago Press, 2005.

25 Ernest A. Zitser. "The Vita of Prince Boris Ivanovich 'Korybut'-Kurakin: Personal Life-Writing and Aristocratic Self-Fashioning at the Court of Peter the Great." Jahrbücher für die Geschichte Osteuropas 59 (2011), pp. 163-194.

26 Ekaterina II. Chesmenskii dvorets. O velichii Rossii. Moscow: EKSMO, 2003, pp. 464-476, p. 472.

27 Ibid., p. 467.

28 Ibid., p. 468.

29 Ibid., pp. 470-471.

30 Ibid., pp. 466-468.

31 Ibid., p. 473. 
Grand Princes of Russia. Especially when compared to the dimwitted Prussians, the Princes of Vladimir, medieval Russian rulers, form a group of utterly worthy men. Surrounded by his dynastic relatives, Alexander Nevsky appears in this room too.

The Princes of Vladimir are shown as a remarkably unified group. "On my right, you see my father, on my left, my brothers, in front of me is Vsevolod, my grandfather, and two of my uncles," says one of them. ${ }^{32}$ The royal author presents them in a positive light: Vsevolod Yurievich is "the founder of the principality of Vladimir"; Vasily Yaroslavich is a relative and peer of most of the monarchs of Europe. Most importantly, the princes of Vladimir "might have known no arithmetic and spelling, but could [...] wage wars." 33

Alexander Nevsky appears as the direct opposite of the kings of Prussia: he "most valiantly and successfully defended his native land and his allies against Swedes, Lithuanians, and Teutonic knights, founders of Livonia and Prussia." 34 The empress calls Alexander a just, wise, and courageous ruler, also mentioning his sainthood. ${ }^{35}$ She concludes that the prince has "nothing in common" with the Prussian dynasty "in this world, or the next." 36

In The Chesme Palace, Catherine II, with her quite dubious hereditary claim to the throne of Russia, also describes several crucial historical figures who, in spite of their own ambitions, did not bring their plans to fruition for a number of reasons. Among the early Romanovs, the empress prefers the "variously gifted" Princess Sofia, Patriarch Filaret, the father of Mikhail, the first tsar of the Romanov dynasty. As a background figure, Tsar Vasily Shuisky appears, who was crowned in 1606 amidst the so-called Time of Troubles, but was then imprisoned and taken to Poland as a prisoner of war.

A special focus is set on the bright personalities of those whose reign was short or ended in a collapse of their power. All of them are presented as capable, yet unfortunate people. There is, for example, Tsar Vasily, who occupied the Russian throne for less than four years. He is said to have been unlucky ("Not everyone has the luck to be [...] well-advised"). Patriarch Filaret, who was de facto ruler for quite some time even though he was never crowned, was a man of "great abilities" and "great discretion." His "skill and wisdom" brought Mikhail Romanov to the throne as the first of his dynasty. ${ }^{37}$ Tsar Fedor, a gifted man of poor health,

32 Ibid., p. 474.

33 Ibid.

34 Ibid.

35 Ibid., p. 473.

36 Ibid., p. 474.

37 Ibid., p. 471. 
ruled most peacefully ("While I lived [...] we were at peace”). ${ }^{38}$ Princess Sofia, a regent of Russia from 1682 to 1689 , is seen as an extraordinary historical figure who held an almost unthinkable position for a woman of a royal dynasty, and whose stay in power was very much viewed as illegitimate. Her brother and rival emperor, the reformer Peter the Great, describes her as follows: "Had not the circumstances rendered her my enemy, I would be glad to make her my adviser. She was variously gifted, but too inclined to follow her maternal relations, especially her uncle Miloslavsky who had a strong predisposition against the family of my mother." 39

The text reveals an attempt to reassess Empress Anna as compared to Elizabeth, Catherine II's godmother and, to a degree, political rival. Having presented Elizabeth as a woman not much engaged in ruling the country, the empress emphasizes Anna's male character-features, stating that she was consequently a better fit for the male-centered political system in Russia. Peter the Great is said to have liked her and to be sad that Anna "was not born a boy." He says to Anna: "I liked you for your masculine and mature mind, presuming thus that you stand further from the inclination to gossip and prattle than other women of our family, who have submitted to slanderous talk." ${ }^{40}$ Furthermore, Catherine II tries to lend additional value to Empress Anna's position in the Romanov family by mentioning that Anna might have been Peter the Great's illegitimate daughter. Peter I says in the text: "Indeed, dear niece, I held you in respect, which is why some slanderously called you my daughter." 41

At the end of the text, Catherine II focuses on the warrior monarchs, such as Peter the Great and Alexander Nevsky. The former, however, does not always appear in the most favorable light, as some researchers suggest ${ }^{42}$ : Peter I, although a "genius endowed with extraordinary talents," is always ready to take sides in family squabbles. ${ }^{43}$ In the text, the right to talk of higher matters belongs to Alexander Nevsky, a warrior and a saint. As has been mentioned, The Chesme Palace, written in the 1780s, should be viewed in the context of the empress's attempt to change the balance between Peter I and Catherine II by downplaying the first Emperor of Russia. ${ }^{44}$ Hence the distribution of roles in the imaginary community of monarchs.

\footnotetext{
38 Ibid., p. 470.

39 Ibid.

40 Ibid., p. 469.

41 Ibid.

42 Skvortsova, "Representing Imperial Power,” p. 467.

43 Ekaterina II, Chesmenskii dvorets, pp. 469-471.

44 Proskurina, Mify imperii, pp. 105-146.
} 
Catherine II herself is conspicuously absent from the text. However, the whole discussion over ruling manners and monarchical virtues aims to fashion the image of one who had mastered rule and embodied the supreme features of an enlightened monarch, that is to say, Catherine II. In The Chesme Palace, she highlights features in others (sadly less successful in retaining power) that she herself is believed to possess: a passion for education, no interest in courtly luxury and female gossiping, a sober (masculine) mind and a gentle heart, and the desire to work for the common good. Moreover, we can find certain echoes of her personal success story, or rather hints at the threats she faced: the lack of good advisors (as in Tsar Vasily Shuisky's case), the disruptive behavior of family members (as in Princess Sofia's case), as well as the problem of the succession (as in the case of Peter the Great).

In order to position herself as a dynastic figure among the Rurikids, the Romanovs, and members of the European monarchical houses, the empress, without actually coming into view, created quite an elaborate textual structure based on the notion of a theater-like play and a view of the portrait as a symbolic object. It provided the empress with a tool to shape her ideas by making heroes exist only within certain limitations. The monarchs in The Chesme Palace are inside portrait frames, and - in a wider perspective - within the palace, maison de plaisance of Catherine II, who appears in this way to be above everyone. The play-like design of the text seems to have been chosen quite deliberately and becomes instrumental for the empress's self-fashioning strategy. It provides freedom within the limits set, encourages interaction between heroes, and so delivers the empress's message in a form accepted in the era of Enlightenment.

Yet, having fashioned herself as a true exception, the empress could not avoid revealing in the text her desire to achieve both legitimacy and her own ruling subjectivity (i.e. to become free of Peter I's patterns, notions, and prescribed roles), and, most of all, to remain on the throne of the Russian Empire. The work concludes with the Russian Prince Vsevolod Yurievich, who claims to have reigned over the principality of Vladimir for thirty-five years. ${ }^{45}$

For Catherine II in the mid-1780s, such a lengthy rule was something to hope for. However, the dream never came true. Having been Russian empress for thirty-four years, she did not beat the record of Vsevolod Yurievich - nor that of Peter the Great, who ruled for more than four decades.

45 Ekaterina II, Chesmenskii dvorets, p. 474. 